\title{
Analysing of the Relationship between Team Cohesion and Prosocial and Antisocial Behaviors of Athletes Taking Groundwork Training in Professional Football Teams
}

\section{Análisis de la relación entre la cohesión Del equipo y las conductas} prosociales y antisociales de los atletas que realizan un entrenamiento preliminar en equipos de fútbol profesional

\author{
Osman Pepe \\ Suleyman Demirel University, Sports Science Faculty / Isparta, Turkey \\ ORCID ID: https://orcid.org/0000-0001-8787-2538 \\ Fahriye Esra Başyiğit Gönendi \\ Suleyman Demirel University, Sports Science Faculty / Isparta, Turkey \\ ORCID ID: https://orcid.org/0000-0002-2075-1157

\section{Burak Gönendi} \\ Mehmet Akif Ersoy University, Institute of Education Sciences / Burdur, Turkey \\ ORCID ID: https://orcid.org/0000-0002-2860-9024

\section{Ayhan Gökkoyun} \\ Kayserispor A.Ş. Kayseri \\ ORCID ID: https://orcid.org/0000-0002-4112-4291
}

*Correspondence

Email: osmanpepe@sdu.du.tr
Cite as:

Pepe, O., Basyiğit Gönendi, FE., Gönendi, B., \& Gökkoyun, A. (2021). Analysing of the Relationship between Team Cohesion and Prosocial and Antisocial Behaviors of Athletes Taking Groundwork Training in Professional Football

Teams. Propósitos y Representaciones, 9 (SPE3), e1158.

Doi: http://dx.doi.org/10.20511/pyr2021.v9nSPE3.1158 


\section{Summary}

In this study, it was aimed to determine the relationship between team cohesion and prosocial and antisocial behaviors of football player candidates taking groundwork training in the professional football team of Kayserispor. The population of the study consisted of 172 football player candidates getting regular football training for at least 1 year in the Kayserispor football team and were in competition status, and the sample consisted of 104 volunteers. As data collection tools, "Personal Information Form", "Youth Sport Environment Questionnaire" and "Prosocial and Antisocial Sports Participation Motives" were used. The data obtained in the study were analyzed in computer environment. Number, percentage, mean, standard deviation were used as descriptive statistical methods in the evaluation of the data. Pearson's correlation was applied between the continuous variables of the study.Among the subtitles of youth athlete team cohesion; among the subtitles of task dimension and pro-social and anti-social behaviors, a moderate positive relationship between pro-social behavior towards teammate and a low level positive relationship between pro-social behavior against the opponent were detected. While a moderate negative relationship was detected between social behavior, there was no relationship between pro-social behavior to the opponent and anti-social behavior to the opponent, one of the subtitles of social dimension and pro-social and anti-social behavior. A low-level negative correlation was found between anti-social behavior towards teammate As a result, in Kayserispor football team, it has been observed that athletes who take groundwork training have a high level of cohesion both in terms of their duties and social aspects, they have positive attitudes and behaviors towards their teammates and the opponent both in or outside of the training or competition, regardless of the situation of the training or the competition, they think that they should stay away from humiliating and disabling attitudes and behaviors. It is thought that this is due to the strong emotional relationship among the team members and the high level of closeness to each other, and the respect they have for the opponent team players who are moving towards the same goal as themselves.

Keywords: Football, Team cohesion, Prosocial-Antisocial Behavior.

\section{Resumen}

En este estudio, se tuvo como objetivo determinar la relación entre la cohesión del equipo y las conductas prosociales y antisociales de los candidatos a futbolistas que realizan entrenamientos de base en el equipo de fútbol profesional de Kayserispor. La población del estudio consistió en 172 candidatos a jugadores de fútbol que recibieron entrenamiento regular de fútbol durante al menos 1 año en el equipo de fútbol de Kayserispor y estaban en estado de competencia, y la muestra consistió en 104 voluntarios. Como herramientas de recopilación de datos, se utilizaron el "Formulario de información personal", el "Cuestionario del entorno deportivo juvenil" y los "Motivos de participación deportiva prosocial y antisocial". Los datos obtenidos en el estudio se analizaron en entorno informático. El número, el porcentaje, la media y la desviación estándar se utilizaron como métodos estadísticos descriptivos en la evaluación de los datos. Se aplicó la correlación de Pearson entre las variables continuas del estudio. Entre los subtítulos de cohesión de equipos de atletas juveniles; entre los subtítulos de dimensión tarea y comportamientos prosociales y antisociales, se detectó una relación positiva moderada entre el comportamiento prosocial hacia el compañero de equipo y una relación positiva de bajo nivel entre el comportamiento prosocial frente al oponente. Si bien se detectó una relación negativa moderada entre el comportamiento social, no hubo relación entre el comportamiento prosocial hacia el oponente y el comportamiento antisocial hacia el oponente, uno de los subtítulos de dimensión social y comportamiento prosocial y antisocial. Se encontró una correlación negativa de bajo nivel entre el comportamiento antisocial hacia el compañero de equipo Como resultado, en el equipo de fútbol de Kayserispor, se ha observado que los atletas que toman entrenamiento de base tienen un alto nivel de cohesión tanto en términos de sus deberes como en aspectos sociales, tienen actitudes y comportamientos positivos hacia sus compañeros y el oponente tanto dentro como fuera del entrenamiento o competición, independientemente de la situación del entrenamiento o 
la competición, piensan que deben mantenerse alejados de actitudes y comportamientos humillantes e incapacitantes. Se piensa que esto se debe a la fuerte relación emocional entre los miembros del equipo y al alto nivel de cercanía entre ellos, y al respeto que tienen por los jugadores del equipo oponente que avanzan hacia el mismo objetivo que ellos.

Palabras clave: Fútbol, Cohesión del equipo, Comportamiento prosocial-antisocial.

\section{Introduction}

The individual goes through different developmental periods on the life line that develops from childhood to old age and shows some physiological and psychological characteristics that are not the same in these periods. It is known that adolescence is not a phenomenon that starts with the end of the childhood period in the individual's development process, but passes until physiologically reaches adulthood, but it is a life and development period that includes other events in human life.

In other words, adolescence is also considered as a transition period in which development and responsibility increase in many areas such as psychological, physical, social and cognitive changes, especially biological changes $(1,2,3)$.

As an adolescent's social space expands outside of his family, the need for interaction and closeness with peers increases. This situation affects the social and moral development of the adolescent. In this respect, sports activities gain more importance in terms of directing the intense energy of the individual to positive areas, learning to act within the plan and program, being disciplined, social and moral development and expressing themselves better, especially during adolescence.

Sports teams create a rich content to investigate the role of peer groups on adolescents' social development (4). It is known that one of these concepts is team cohesion. The word cohesion is conceptually was defined for the first time by Moreno and Jenning as "the forces that enable people to stay in the groups of which they are a member" (5). Team cohesion is a mechanism that creates various effects on team dynamics and reinforces group processes, which preserves the development of highly functional groups and the continuity of this development (6).

Competition and the spirit of competitiveness in team sports changes both the relationships of the players with their teammates and their attitude towards the opponent. These behaviors directly affect the success and performance of the athlete and the team. The identities formed by adolescents by joining a sports club in this process constitute an important component of the selfconcept and are critical in establishing moral values in youth sports.

While sports contributes significantly to the psychological development of the person as well as physical development, it is also seen as a supporter of the moral character development of the person or people (7).

When the literature is examined, the concept of morality in sports has also been examined as antisocial-prosocial behaviors. In previous studies (8), prosocial behavior was defined as voluntary help or benefit towards someone else. This definition is also used in current studies. In contrast, antisocial behaviors are defined as deliberately harming another individual or group. Athletes are faced with many prosocial behaviors such as helping the fallen athlete, encouraging and supporting their teammates, or helping the injured player (9). In contrast to these behaviors, they may also display antisocial behaviors such as attempting to injure their opponent and arguing with their teammates $(9,10)$.

In the literature review conducted by the researchers, it was observed that there were studies examining team cohesion and antisocial-prosocial behaviors in many branches of team sports and in many age categories $(11,12,13)$. However, there is no study examining the relationship between these two concepts. From this point of view, it is thought that this study will contribute to the literature.

The preference of the target group in this study as football athletes was primarily due to the fact that they are one of the team sports with high physical contact, their popularity and the fact that physical / verbal aggression can be easily observed. 
In the study we conducted, it was aimed to examine how the team cohesion of athletes who took groundwork training in professional football teams affect the level of antisocial - prosocial behaviors.

\section{Methodology}

In the research, descriptive and correlational survey models were used. Descriptive survey models are research models that define a past or present situation under its own conditions and as it is, while correlational survey models aim to determine the presence and/or degree of change between two or more variables (14).

\section{Forming Volunteer Groups}

In this study, it was aimed to determine the relationship between team cohesion and prosocial and antisocial behaviors of youth football player candidates in the professional football team of Kayserispor. The population of the study consisted of 172 football player candidates who took regular football training for at least 1 year in the Kayserispor football team and were in competition status, and the sample consisted of 104 volunteers. As data collection tools, "Personal Information Form", "Youth Sport Environment Questionnaire" and "Prosocial and Antisocial Sports Participation Motives" were used.

Table 1. Descriptive Statistics of Participants

\begin{tabular}{cccc}
\hline Variables & Groups & $\mathrm{N}$ & $\%$ \\
\hline \multirow{2}{*}{ Age } & $12-13$ & 37 & 35,6 \\
& $14-15$ & 37 & 35,6 \\
& 16 and more & 30 & 28,8 \\
& Total & 104 & 100 \\
\hline \multirow{2}{*}{ Sports Age } & $0-2$ & 36 & 34,6 \\
& $3-4$ & 30 & 28,8 \\
& 5 and more & 38 & 36,5 \\
& Total & 104 & 100 \\
\hline
\end{tabular}

According to the age groups of the football player candidates participating in the study, $35.6 \%$ of them were $12-13,35.6 \%$ of them were $14-15,28.8 \%$ of them were 16 years and more, and $34.6 \%$ of them were $0-2,28.8 \%$ of them were $3-4,36.5 \%$ of them were 5 years and more.

\section{Data Collection Tools}

\section{Personal Information Form}

"Personal Information Form" was used by the researcher to determine the age and sports age levels of the participants in order to collect data on descriptive statistics of the football player candidates.

Youth Sport Environment Questionnaire: The scale developed by Eys et al. in 2009 consists of 18 items and 2 sub-dimensions: task and social dimensions (15). The scale was adapted to Turkish by Sezer and Kocaekşi in 2018. With the reliability studies performed, it was seen that the internal consistency coefficients regarding the reliability of the scale and the structures within the scale were higher than .70 , and the scale was found to have a very good level of reliability (Task Cohesion $=.87$, Social Cohesion $=.87$, Overall $=.89)(16)$.

Prosocial and Antisocial Behavior Scale: The pro-social and anti-social behavior scale in sports, which was developed by Kavussanu and Boardley in 2009 (9) and adapted in Turkish by Balç1kanlı in 2013, is a 5-point Likert-type scale and consists of 20 items and 4 sub-dimensions. The lowest 20 and the highest 100 points can be obtained on the scale. Of the 20 items in the scale, 7 are about pro-social behaviors and 13 are about anti-social behaviors. The internal consistency analysis results of the scale for prosocial behavior to teammate was found to be .74, anti-social behavior towards teammate was found to be .70, pro-social behavior to the opponent was found to be.71 and antisocial behavior to the opponent was found to be .68 (17). 
Statistical Analysis of Data

Application of the Kolmogorov-Smirnov test is only one of the methods used to examine the state of normality. The skewness and kurtosis distributions according to the statistics of the data obtained in the study and the results of the Kolmogorov-Smirnov test were given in Table 2.

Table 2. Skewness-Kurtosis and Kolmogorov-Smirnov Test Significance Level Results of Participants' Scale Scores

\begin{tabular}{lcccc}
\hline & $\mathrm{N}$ & Skewness & Kurtosis & $\mathrm{p}$ \\
\hline Task Cohesion & 104 & -1.396 & 1.574 & .000 \\
Social Cohesion & 104 & -1.343 & 1.410 & .000 \\
\hline Prosocial Behavior to a Teammate & 104 & -.783 & -.595 & .000 \\
Prosocial Behavior to the Opponent & 104 & -.798 & -.170 & .000 \\
Antisocial Behavior to Teammates & 104 & 1.402 & 1.396 & .000 \\
Antisocial Behavior to Opponent & 104 & 1.126 & 1.194 & .000 \\
\hline
\end{tabular}

When Table 2 was examined, it was observed that the deviations from normality of the scores of the participants from the Youth Sport Environment Questionnaire and prosocial and antisocial behavior scales are significant. When the normal distribution curves were examined, it was seen that there were no excessive deviations from the normality. It has been stated that it is desired that the coefficients of kurtosis and skewness are ideally between \pm 1 , but values between \pm 2 are also acceptable (18). It was decided to use parametric statistical analysis tests since it was seen that the skewness-kurtosis values of the scores were not at extreme levels, were in the \pm 2 range and there were no excessive deviations in the normal distribution curves.

The data obtained in the study were analyzed in computer environment. Number, percentage, mean, standard deviation were used as descriptive statistical methods in the evaluation of the data. Pearson's correlation was applied between the continuous variables of the study.

\section{Results}

Table 3. Descriptive Statistics of the Participants' Scores Obtained from Youth Sport Environment Questionnaire and Prosocial and Antisocial Behavior Scales

\begin{tabular}{|c|c|c|c|c|}
\hline & $\mathrm{N}$ & Min & Max & $\mathrm{X} \pm \mathrm{SD}$ \\
\hline Task Cohesion & $\begin{array}{c}10 \\
4\end{array}$ & 22.00 & 72.00 & $62.318 \pm 10.558$ \\
\hline Social Cohesion & 104 & 9.00 & 72.00 & $56.192 \pm 14.791$ \\
\hline Prosocial Behavior to a Teammate & 104 & 14.00 & 20.00 & $18.250 \pm 1.889$ \\
\hline Prosocial Behavior to the Opponent & 104 & 5.00 & 15.00 & $12.635 \pm 2.462$ \\
\hline Antisocial Behavior to Teammates & 104 & 5.00 & 14.00 & $6.740 \pm 2.109$ \\
\hline Antisocial Behavior to Opponent & 104 & 8.00 & 30.00 & $13.164 \pm 4.611$ \\
\hline
\end{tabular}

When Table 3 was examined, it was found that the football player candidates participating in the study were at the level of $62.318 \pm 10.558$ in the subtitle of Youth Sport Environment Questionnaire and 56.192 \pm 14.791 in the subtitle of social cohesion. In the prosocial and antisocial behavior subtitles, it was determined that prosocial behavior to teammate was at the level of $18.25 \pm 1.889$, prosocial behavior to opponent was at the level of $12.635 \pm 2.462$, antisocial behavior to teammate was at the level of $6.740 \pm 2.109$, and antisocial behavior to opponent was at the level of $13.164 \pm 4.611$. 
Table 4. The Relationship Between Youth Sport Environment Questionnaire and Prosocial and Antisocial Behaviors of Participants

\begin{tabular}{llllll}
\hline & & $\begin{array}{l}\text { Prosocial Behavior } \\
\text { to a Teammate }\end{array}$ & $\begin{array}{l}\text { Prosocial } \\
\text { Behavior to } \\
\text { the } \\
\text { Opponent }\end{array}$ & $\begin{array}{l}\text { Antisocial Behavior } \\
\text { to Teammates }\end{array}$ & $\begin{array}{l}\text { Antisocial } \\
\text { Behavior to } \\
\text { Opponent }\end{array}$ \\
\hline Task & $\mathrm{r}$ & .325 & .247 & -.523 & -.372 \\
Cohesion & $\mathrm{p}$ & .001 & .011 & .000 & .000 \\
\hline Social & $\mathrm{r}$ & .275 & .158 & -.210 & -.142 \\
Cohesion & $\mathrm{p}$ & .005 & .108 & .032 & .151 \\
\hline
\end{tabular}

When Table 4 was examined, among the subtitles of Youth Sport Environment Questionnaire; From the subtitles of task cohesion and prosocial and antisocial behaviors, while there was a positive moderate level of prosocial behavior towards teammate $(\mathrm{r}=.325, \mathrm{p}=.001)$, and a positive low level of prosocial behavior towards the opponent $(\mathrm{r}=.247, \mathrm{p}=.011)$, a moderate negative correlation was found between antisocial behavior towards teammate $(r=-.523, p=.000)$ and antisocial behavior towards opponent $(\mathrm{r}=-.372, \mathrm{p}=.000)$.

From social cohesion sub-dimension and prosocial and antisocial behavior subtitles, while there was no correlation between prosocial behavior towards opponent $(\mathrm{r}=.158, \mathrm{p}=.108)$ and antisocial behavior to opponent $(\mathrm{r}=-.142, \mathrm{p}=.151)$, it was found that there was a low level positive correlation between prosocial behavior to teammate $(\mathrm{r}=.275, \mathrm{p}=.005)$ and a low level negative correlation between antisocial behavior towards teammate $(\mathrm{r}=-.210, \mathrm{p}=.032)$.

\section{Discussion and Conclusion}

The popularity of the football branch, psychological factors and sportive struggle for success have made the prosocial and antisocial behaviors, in and out of the team, group cohesion inside and outside the team visible.

The concept of cohesion is expressed as a dynamic process that reflects the tendency of member individuals to interlock and stay together in order to achieve a group's goals and objectives (19), and a common bond/attraction that enables the individuals in the group to stay together and want to work together (20). There are many factors for teams to be successful. Some of these factors are team unity, the members' sense of belonging to the team, and their commitment. The equivalent of this unity in social psychology is called team cohesion (21).

In the literature review conducted by the researcher, it has been the subject of studies reporting the positive relationship between team cohesion and self-efficacy (22), motivational climate (23), athlete satisfaction with personality interaction $(24)$, performance $(25,26,27)$, perception of success $(28,29)$, sports satisfaction (30) collective efficacy and motivational climate (31).

The desire to win in sports sometimes leads to violation of sportive rules, thus going beyond the aspects of respect, peace and socialization inherent in sports, resulting in the emergence of aggressive and immoral behaviors.

Kavussanu (32) expressed morality in sportive context in two dimensions as pro-social and antisocial behaviors. Pro-social behavior is defined as voluntary help or benefit towards another person while anti-social behavior is defined as willful harm to another individual or group (33). In the literature review conducted by the researcher, it has been the subject of research reporting the relationship between pro-social and anti-social behaviors, goal orientation and motivational climate $(37,38)$ perfectionism $(39,40)$ aggression (41) fear of failure (42), empathy for attention and performance (43).

Among the subtitles of youth athlete team cohesion; among the subtitles of task dimension and pro-social and anti-social behaviors, a moderate positive relationship between pro-social behavior towards teammate and a low level positive relationship between pro-social behavior against the opponent were detected. While a moderate negative relationship was detected between social behavior, there was no relationship between pro-social behavior to the opponent and anti-social behavior to the opponent, one of the subtitles of social dimension and pro-social and anti-social 
behavior. A low-level negative correlation was found between anti-social behavior towards teammate (Table. 4).

In developing and changing football, the concept of "being a team" has increased its importance even more, and concepts such as "team player" and "team success" have come to the fore at every level from youth teams to A teams.

In cases where the concept of being successful requires members to keep the goals of the group above their individual goals, success may depend on the development of the "we" feeling for the members and becoming more important than the "I" feeling (45). In case of success in team sports, it can direct team members to act together. Thus, it is believed that it provides a tool for teaching athletes, cooperation with their teammates, harmony and finding solutions to moral contradictions. In addition, although the approach that sports constructs character is very dominant in sports environments, there is evidence that competitive sports have a negative effect on character development. Competition can create moral problems, reduce pro-social behavior, and support anti-social behavior (46).

As a result, in Kayserispor football team, it has been observed that athletes who take groundwork training have a high level of cohesion both in terms of their duties and social aspects, they have positive attitudes and behaviors towards their teammates and the opponent both in or outside of the training or competition, regardless of the situation of the training or the competition, they think that they should stay away from humiliating and disabling attitudes and behaviors. It is thought that this is due to the strong emotional relationship among the team members and the high level of closeness to each other, and the respect they have for the opponent team players who are moving towards the same goal as themselves.

\section{References}

Senemoğlu, N (1997). Gelişim, Öğrenme ve Öğretim: Kuramdan Uygulamaya, Ankara: Spot Matbac1lik, 56-57.

Selçuk, Ziya (2004). Gelişim ve Öğrenme, 10. Baskı Ankara: Nobel Yayın Dağıtım:37

Steinberg, L (2007). Ergenlik. Ankara: İmge kitapevi: 22.

Holt, N. L., Black, D. E., Tamminen, K. A., Fox, K. R., \& Mandigo, J. L. (2008). Levels of Social Complexity and Dimensions of Peer Experiences in Youth Sport. Journal of Sport \& Exercise Psychology, 30, 411-431.

Moreno, J. L., Jennings, H. H.(1991). Statistics of social configurations.Sociometry, 1:342-374.

Mohiyeddini ve LeBlanc, Advances In The Psychology of Sports and Exercise, 2013, Chapter 5: Group Cohesion, Sport and Exercise :77-95.

Bredemeier BJL, Shields DL. Moral assessment in sport psychology, In: Duda JL, editör, Advances in sport and exercise psychology measurement, Morgantown; 1998.

Eisenberg, N. \& Fabes EA. (1998). The Roots of Prosocial Behavior in Children. In: Cambridge University Press. Cambridge, UK.

Kavussanu M, Boardley ID. (2009) The Prosocial and Antisocial Behavior in Sport Scale. J Sport Exerc Psychol;31(1):97-117.

Kavussanu M, Seal AR, Phillips DR. (2006). Observed prosocial and antisocial behaviors in male soccer teams: Age differences across adolescence and the role of motivational variables. $\mathrm{J}$ Appl Sport Psychol; 18(4):326-44.

Balçıkanlı, GS, Yıldıran İ. (2018). Elit Salon Hokeyi Oyuncularında Empatik Beceri İle Prososyal Davranışlar Arasındaki İlişsi Gazi Beden Eğitimi Ve Spor Bilimleri Dergisi Gazi Journal Of Physical Education And Sport Sciences, 23(1), 1-8

Özdemir, İ. (2019). Takım Sporları ile Uğraşan Yetişkin Sporcuların Prososyal ve Antisosyal Davranışlarının Belirlenmesinde Mükemmeliyetçilik ve Başarı (Order No. 28244844). Marmara Üniversitesi Sağlık Bilimleri Enstitüsü Beden Eğitimi ve Spor Anabilim Dalı Yüksek Lisans Tezi, İstanbul.

Tekkurşun Demir, G, Namlı, S, Cicioğlu İH. (2018) Futbol ve Voleybol Oyuncularının Grup Sargınlığı Ve Empati Düzeyi Socıal Mentalıty And Researcher Thınkers Journal Vol 4 / Issue 13 / Pp:846-859. 
Karasar, N. (2004). Bilimsel Araştırma Yöntemi, Nobel Yayıncılık, Ankara, 52

Eys MA, Lougheed T, Bray SR, Carron AV. (2009). Development of a Cohesion Questionnaire for Youth: The Youth Sport Environment Questionnaire, Kinesiology and Physical Education Faculty Publications, 31(3), 390- 408

Sezer U ve Kocaekşi S. (2018). Genç Sporcu Takım Sargınlığı Ölçeği’nin (GSTSÖ) Psikometrik Özellikleri: Geçerlik ve Güvenirlik Çalışması Spor Bilimleri Dergisi Hacettepe Journal of Sport Sciences; 29 (3), 105-114.

Balçıkanlı GS. (2013). The Turkish Adaptation of the Prosocial and Antisocial Behavior in Sport Scale (PABSS). Int J Humanit Soc Sci;3(18):271-276

George D, Mallery P. (2016). IBM SPSS Statistics 23 Step by Step: A Simple Guide and Reference. New York: Routledge; 112-120.

Carron, A. V. (1982). Cohesiveness in sport groups: Interpretations and considerations, J. Sport Psychol, 123-138.

Casey-Campbell, M. \& Martens, M. L. (2009). Sticking itall together: A critical assessment of the group cohesion-performance literature. Int. J. Manag. Rev., 11, 223-246.

Toros, T. (2011). Genç Erkek Basketbolcularda, Turnuva Öncesi ve Turnuva Sonrası Sporcuların Algıladıkları Antrenörlük Davranışı, Hedef Yönelimleri, Takım Sargınlığı, Algılanan Motivasyonel İklim ve Kolektif Yeterlik Arasındaki Farklılığın Analizi. Pamukkale Journal of Sport Sciences, 2(1), 27-39.

Aydın F. (2018). Ankara İlindeki Profesyonel Kadın ve Erkek Futbol Takımlarının ÖzYeterlik ve Sargınlık Algıları Arasındaki İlişki. Ankara Üniversitesi Sağlık Bilimleri Enstitüsü, Yüksek Lisans Tezi, Ankara.

Durdubaş D. (2013). Bir Sezon Boyunca Takım Hedef Belirleme Yoluyla Uygulanan Takım Oluşturma Müdahalesinin Takım Sargınlığı ve Motivasyonel İklim Üzerine Etkisinin Belirlenmesi. Hacettepe Üniversitesi Sağlık Bilimleri Enstitüsü, Yüksek Lisans Tezi,, Ankara

Erbektaş E, 2018. Kişilik Özellikleri ve Takım Sargınlığı Etkileşiminin Sporcu Doyumuna Olan Etkisinin İncelenmesi. Abant İzzet Baysal Üniversitesi Sosyal Bilimler Enstitüsü, Yüksek Lisans Tezi, Bolu

Kocaekşi S, Koruç Z. (2012). Başarılı ve Başarısız Hentbol Takımlarının Grup Sargınlığı, Kaygı, Güdülenme ve Yeterlik Düzeylerinin Karşılaştırılması. Spor Bilimleri Dergisi;23(3):129143.

Annelies EM, Carsten KW (2001). Personality in teams: 1ts relationship to social cohesion, task cohesion, and team performance. European Journal of Work and Organizational Psychology;10(2):97-120.

Bray CD, Whaley DE (2001). Team cohesion,effort and objetive individual performance of high school basketball players. Sport Psychologist;6:260-275.

Carron AV, Bray SR, Eys MA (2002). Team cohesion and team success in sport. Journal of Sports Sciences;20(2):119-126.

Öcel H (2009). Takım sporu yapan oyuncularda kollektif yeterlilik, öz yeterlilik ve sargınlık ile başarı algıları ve beklentileri arasındaki ilişki. Edebiyat Fakültesi Dergisi ;26(2): 155-174.

Dhurup M, Reddy L (2013). Social and task cohesion and the relationship with team sport satisfaction and academic performance among a first year university cohort: social psychology. African Journal For Physical Healt Education, Recreaction and Dance;19(2):381-393.

Garcia-Calvo T, Leo FM, Gonzalez-Ponce I, Sanchez-Miguel PA, Mouratidis A, Ntoumanis N.(2014). Perceived coach-created and peer-created motivational climates and their associations with team cohesion and athlete satisfaction: evidence from a longitudinal study. Journal of Sports Sciences;32(18):1738-1750.

Kavussanu M. (2008). Moral behaviour in sport: a critical review of the literature. Int Rev Sport Exerc Psychol;1(2):124-38.

Eisenberg, N. \& Fabes EA. (1998). The Roots of Prosocial Behavior in Children. In: Cambridge University Press. Cambridge, UK.

Kavussanu M, Boardley ID. (2009). The Prosocial and Antisocial Behavior in Sport Scale. J Sport Exerc Psychol;31(1):97-117. 
Kavussanu M, Seal AR, Phillips DR (2006). Observed prosocial and antisocial behaviors in male soccer teams: Age differences across adolescence and the role of motivational variables. J Appl Sport Psychol;18(4):326-44.

Demir, T. G., Namlı, S., Hazar, Z., Türkeli, A., \& Cicioğlu, İ. H. (2018). Bireysel ve takım sporcularının karar verme stilleri ve mental iyi oluş düzeyleri. CBÜ Bed. Eğt. Spor Bil. Dergisi, 13(1), 176-191.

Boardley ID, Kavussanu M. (2009). The influence of social variables and moral disengagement on prosocial and antisocial behaviours in field hockey and netball. Journal of Sports Sciences; 27(8), 843-854.

Hodge K. Lonsdale C (2011). Prosocial and Antisocial Behavior in Sport: The Role of Coaching Style, Autonomous vs. Controlled Motivation, and Moral Disengagement. Journal of Sport and Exercise Psychology; 33, 527-547.

Hadley A. (2015). Predicting moral behaviour in sport: Individual and interactive relationships 1nvolving motivational climate, gender, and perfectionism. Lakehead University, Unpublished Masters Thesis, Canada.

Özdemir İ (2019). Takım Sporları İle Uğraşan Yetişkin Sporcuların Prososyal Ve Antisosyal Davranışlarının Belirlenmesinde Mükemmeliyetçilik Ve Başarı Hedeflerinin Rolü Marmara Üniversitesi Sağlık Bilimleri Enstitüsü İ Beden Eğitimi Ve Spor Anabilim Dalı Lisans Üstü Tezi İstanbul.

Micai M, Kavussanu M, Ring C. (2015). Executive Function Is Associated With Antisocial Behavior and Aggression in Athletes. Journal of Sport and Exercise Psychology; 37, 469476.

Sagar SS, Boardley D, Kavussanu M. (2011). Fear of failure and student athletes interpersonal antisocial behaviour in education and sport. British Journal of Educational Psychology; 81, 391-408.

Al-yaaribi A, Kavussanu M, Ring C (2018). The Effects of Prosocial and Antisocial Behaviors on Emotion, Attention, and Performance During a Competitive Basketball Task. Journal of Sport and Exercise Psychology; 40(6), 1-9.

Balçıkanlı GS, Yıldıran İ. (2018). Elit Salon Hokeyi Oyuncularında Empatik Beceri ile Prososyal Davranışlar Arasındaki İlişki; 23(1), 1-8.

Singer NR, Murphey M, Tennant KL. (1993) Handbook of Research on Sport Psychology. New York: Macmillan.

Tiryaki Ş. (2006). Spor Psikolojisi: Kavramlar, Kuramlar ve Uygulama, Eylül Yayınları, Ankara, 13-43. 